\title{
PROPERTIES OF ANCIENT STYLE HANDMADE CLAY BRICKS USING BOTTOM ASH
}

\author{
Mehmet CANBAZ ${ }^{1, *}$, Uğur ALBAYRAK ${ }^{1}$ \\ ${ }^{1}$ Department of Civil Engineering, Faculty of Engineering, Eskişehir Osmangazi University, 26480, Eskişehir, Turkey
}

\begin{abstract}
Ancient style handmade bricks are widely used as an infill wall material in masonry and also historical structures in Turkey. Light weight brick production is very important in terms of reducing the dead load of structure subjected to earthquake. Safety and long service life of masonry buildings depends on durability of clay bricks. These bricks with bottom ash were manufactured on the weight percentage of 0-40\% interval instead of clay. Brick samples were tested under 50-100 freezing thawing cycle. As a result of Freezing-thawing durability test; compressive strength loss, ultrasonic pulse velocity loss and unit weight loss have been determiened. As a conclusion; mid-strength, lightened handmade bricks can be obtained using bottom ash.
\end{abstract}

Keywords: Bottom ash, Freeze-thaw effect, Handmade brick

\section{INTRODUCTION}

Baked clay is used to make bricks as construction material for ancient times but also nowadays. People have used brick for building purposes for thousands of years. The earliest bricks, made in areas with warm climates, were simply placed in the sunlight for hardening. Sun-dried bricks, which were used extensively in ancient times [1]. Handmade bricks were produced by primitive methods at ancient times but manufactured at the factories today. Bricks are being extensively used in masonry construction economically and the production technique is easy to manufacture [2-3]. It can be used in unreinforced masonry buildings that are a type of building where load bearing brick walls and also used in infill walls for R.C. framed buildings. Main advantage of baked clay material from other infill material is its strength. Production of brick elements increases day by day because of easy and economic manufacturing however clay deposits which are important for agriculture decreases. For this purposes, many research are conducted to obtain good quality bricks to reduce by using many binding materials [4-7]. Using of 30-40\% fly ash in the production of bricks, decrease almost $10 \%$ strength. On the other hand carbonation is protected with fly ash [8]. Availability of perlite and diatomite were evaluated so desired mechanical properties have been obtained using of $20 \%$ diatomite [9]. Lime-based bricks were produced using fly ash-desulphurization gypsum and it was seen as advantageous for the use of solid wastes [10]. Waste pomace, marble powder, boron, agricultural bio wastes and perlite can be used in bricks production efficiently [11-15]. Fly ash, sand and lime were mixed in different proportions under high pressure steam cure and this mixture was used in brick production. As a result this light bricks provide high heat insulation [16]. Various brick wastes were used to investigate temperature changes in the production [17]. Pumice stone used as raw material for bricks investigated with the effect of the size and the amount of pumice [18]. In this study production of handmade bricks using bottom ash is evaluated. Bottom ash refers to part of the non-combustible residues of combustion which is solid waste from thermal reactors using coals [19]. The storage of this bottom ash is very harmful to the environment to the cost of economically large. Bottom ash is not widely used in construction industry as much as fly ash. Especially used in roads or pavements like as infill materials. Because unburned carbon percentage of bottom ash is high, it used as infill material for roads [20]. Bottom ashes provide fullness in microstructure and improve impermeability so freezing-thawing strength increased [21]. Under 
freezing-thawing affect, brick temperature is low then capillary water freezes in the gaps. The volume of water which turned into ice increases $9 \%$ approximately. If there is not enough space and turn into ice water, with the gaps resulting from volume expansion of the adjacent surfaces will lead to cracking of the brick is composed of large stresses. Increase in temperature melts the ice and waters are moving into the cracks. After freezing-thawing cycles cracks are growing and ramifying more. Under freezingthawing cycles even the best quality bricks may be damaged within a year or two. In Turkey, number of freeze-thaw changes by region climates. Map of Turkey's annual freeze-thaw cycle is given in Figure 1 [22]. Excessive temperature differences cause important durability problems in terms of freezing thawing effect in Anatolia. Water absorption problems may be monitored for the structures built with ancient style bricks, where the places near river or seaside. High strength handmade bricks may be chip off into pieces exposed to freezing thawing, and then they lost their strengths completely. Handmade bricks were produced by primitive methods at ancient times but manufactured at the factories today. The storage of this bottom ash is very harmful to the environment to the cost of economically large.

In this study reducing the weight of handmade bricks using bottom ash is aimed thence these bricks can be used in unreinforced masonry buildings that are a type of building where load bearing brick walls and also used in infill walls for R.C. framed buildings. Even if the strength of the bricks used in buildings are enough, this type of bricks can be loss its strength because of freeze-thaw caused by water absorption. In this manner one of the biggest problem which is freezing and thawing durability were examined in this study.

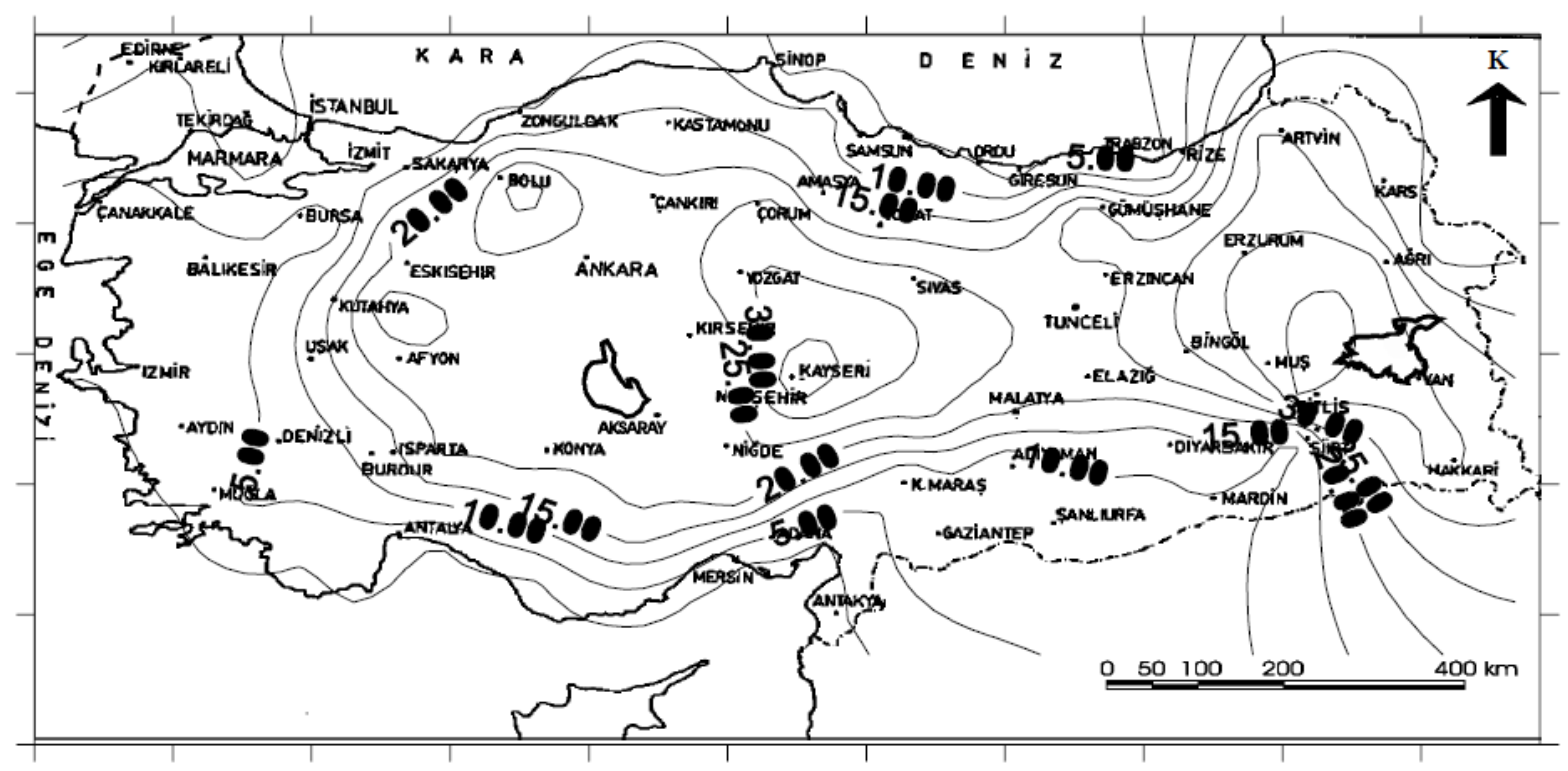

Figure 1. Map of Turkey's annual freeze-thaw cycle

\section{EXPERIMENTAL STUDY}

\subsection{Materials}

Clay: Clay is the most important raw material used for brick baking. In this study, Kuruçay Region clay were used to produce handmade samples shown in Figure 2. 


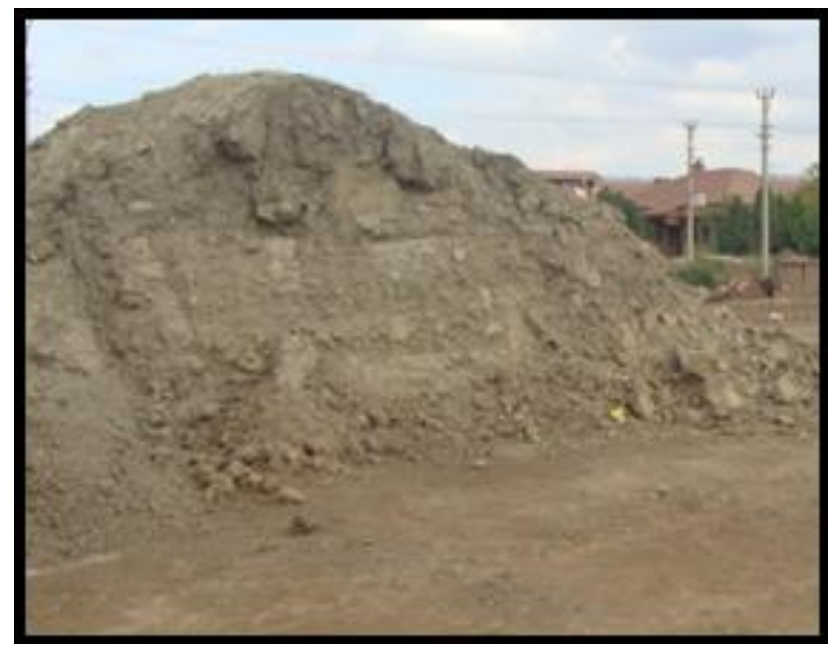

Figure 2. Clay from Çorum Kuruçay region

Chemical analysis of the clay used in the study given in Table 1 . There are not any hazardous compounds in clay samples for brick production.

Table 1 Chemical analysis of clay used for brick and bottom ash

\begin{tabular}{cccccccccccc}
\hline Compound, \% & $\mathrm{SiO}_{2}$ & $\mathrm{Al}_{2} \mathrm{O}_{3}$ & $\mathrm{Fe}_{2} \mathrm{O}_{3}$ & $\mathrm{MgO}$ & $\mathrm{CaO}$ & $\mathrm{Na} 2 \mathrm{O}$ & $\mathrm{K}_{2} \mathrm{O}$ & $\mathrm{Cl}$ & $\mathrm{SO}_{3}$ & $\mathrm{Ta}_{2} \mathrm{O}$ & $\mathrm{TiO}_{2}$ \\
Clay & 55.66 & 21.57 & 12.21 & 1.34 & 1.05 & 1.30 & - & - & - & 3.94 & 0.93 \\
Bottom ash & 51.51 & 18.76 & 9.57 & 0.93 & 5.08 & 0.52 & 2.56 & 0.005 & 0.007 & - & - \\
\hline
\end{tabular}

Bottom Ash: Seyitömer Thermal reactor's bottom ashes were used in the production of Lightened Handmade Brick. Chemical analysis of bottom ash used in the study shown in Table 1. The Ggranulometry of used bottom ash is given in Table 2 .

Table 2 Granulometry of bottom ash

\begin{tabular}{ccccc}
\hline Particle size, $\mathrm{mm}$ & 2 & 1 & 0.5 & 0.25 \\
$\%$ & 100 & 100 & 85 & 40 \\
\hline
\end{tabular}

Water: Çorum tap water that the properties of given in Table 3 is used.

Table 3 Chemical analysis of water used

\begin{tabular}{|c|c|c|c|c|c|c|c|}
\hline $\begin{array}{l}\mathrm{pH} \\
7.27\end{array}$ & \multicolumn{2}{|c|}{$\begin{array}{c}\text { Calcium (mg/lt) } \\
21.10\end{array}$} & \multicolumn{2}{|c|}{$\begin{array}{c}\text { Magnesium (mg/lt) } \\
12.20\end{array}$} & $\begin{array}{c}\text { Chloride (mg/lt) } \\
9.82\end{array}$ & \multicolumn{2}{|c|}{$\begin{array}{c}\text { Sulfate }\left(\mathrm{SO}_{4}{ }^{-2}\right)(\mathrm{mg} / \mathrm{lt}) \\
45.00\end{array}$} \\
\hline \multicolumn{2}{|c|}{$\begin{array}{c}\text { Sodium }(\mathrm{mg} / \mathrm{lt}) \\
8.30\end{array}$} & Pota & & \multicolumn{2}{|c|}{$\begin{array}{c}\text { Hardness }\left(\mathrm{mg} \mathrm{CaCO}_{3} / \mathrm{lt}\right) \\
103\end{array}$} & \multicolumn{2}{|c|}{$\begin{array}{c}\text { Total Alkalinity }\left(\mathrm{mg} / \mathrm{lt} \mathrm{CaCO}_{3}\right) \\
64\end{array}$} \\
\hline \multicolumn{2}{|c|}{$\begin{array}{c}\text { Fluoride }(\mathrm{mg} / \mathrm{lt}) \\
0.08\end{array}$} & Carbon & & $\begin{array}{c}\text { Bicarbonate }(\mathrm{mg} / \mathrm{lt}) \\
78.00\end{array}$ & $\begin{array}{c}\text { Chlorine (mg/lt) } \\
1.20\end{array}$ & $\begin{array}{l}\text { Nitrite }(\mathrm{mg} / \mathrm{lt}) \\
<0.006\end{array}$ & $\begin{array}{c}\text { Nitrate }(\mathrm{mg} / \mathrm{lt}) \\
0.87\end{array}$ \\
\hline
\end{tabular}

\subsection{Method and Tests}

Handmade bricks with bottom ash by the weight percentage of $0 \%, 10 \%, 20 \%$ and $40 \%$ which has been included in all mixtures instead of clay. Natural bottom ash were replace with clay without any operations because the chemical compounds are similar to clay. The prepared mixture blended homogeneously and placed shown in Figure 3. 


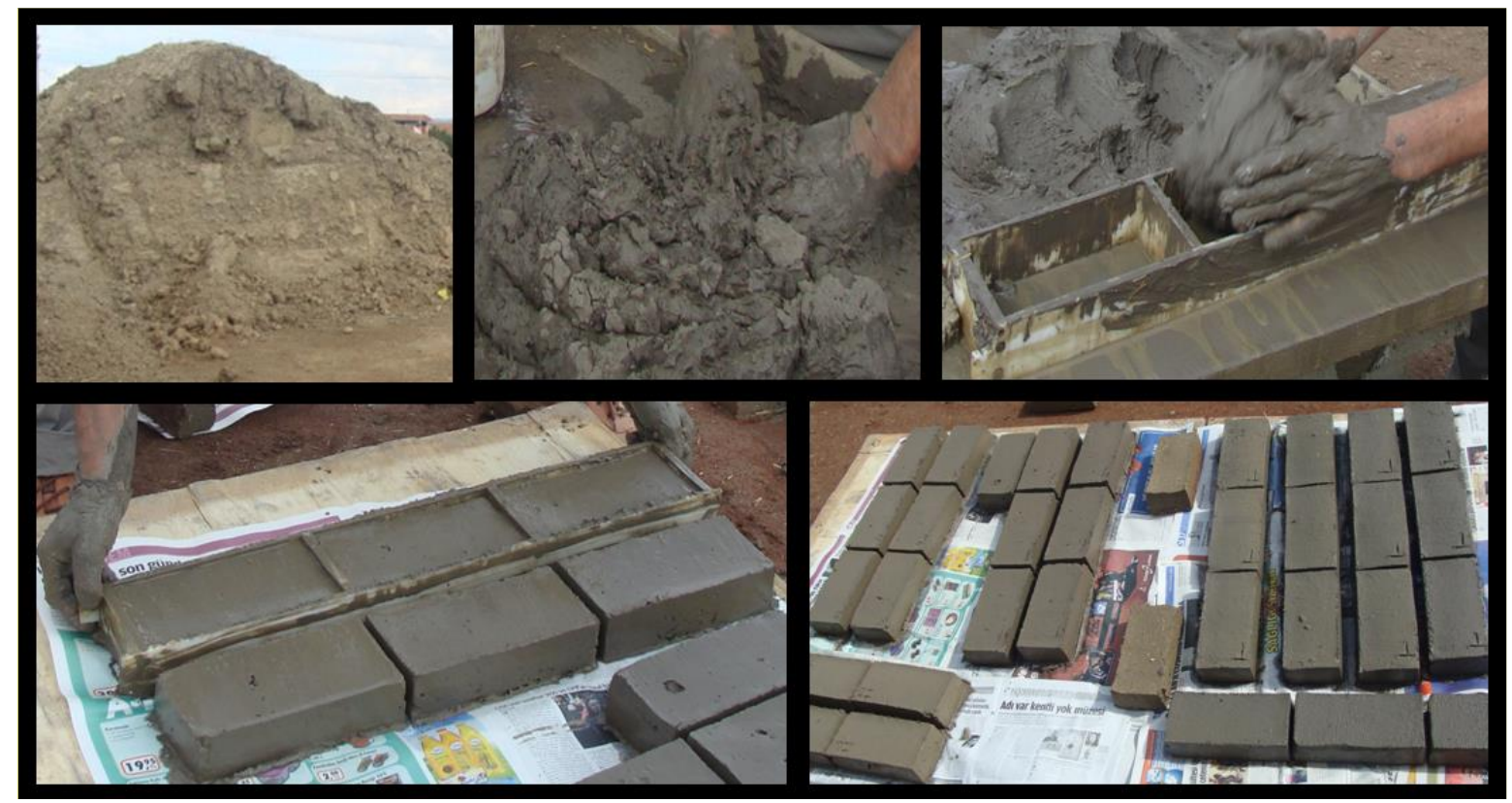

Figure 3. Production of handmade brick with bottom ash

Wooden molds which are formed by nailing the planks together tightly to create an open box with no gaps are used to form the clay bricks. The standard brick size is $5 \times 9 \times 19 \mathrm{~cm}$, the interior of the mold needs to be this size. The molds were lubricated before setup to provide smooth surfaces and were filled with the brick mixture and trim any excess along the edges of the box so surfaces were leveled. Samples were removed from the molds quickly and carefully. Brick samples produced by each mixture have a separate symbol. The samples were placed on a level surface wooden board which was prepared proper with standard brick dimensions. Brick samples were rotated in first two hours to prevent deformation so other surfaces dried. The bricks which the process of drying completed were placed in to the kiln in Figure 4. Opening of the kiln built with bricks and plastered to close the opening so energy losing want to be prevented. The bricks which the process of drying completed were placed in to the kiln in Figure 4. After the kiln prepared, coal dust is injected at $1000^{\circ} \mathrm{C}$ under atmospheric conditions so baking process done with the velocity $150{ }^{\circ} \mathrm{C} /$ hour. The kiln kept at a constant temperature for 2 hours at the $1000{ }^{\circ} \mathrm{C}$, and then the kiln has allowed the cool until the temperature decreased to $200{ }^{\circ} \mathrm{C}$ so the samples were removed from the kiln and cooled to room temperature.

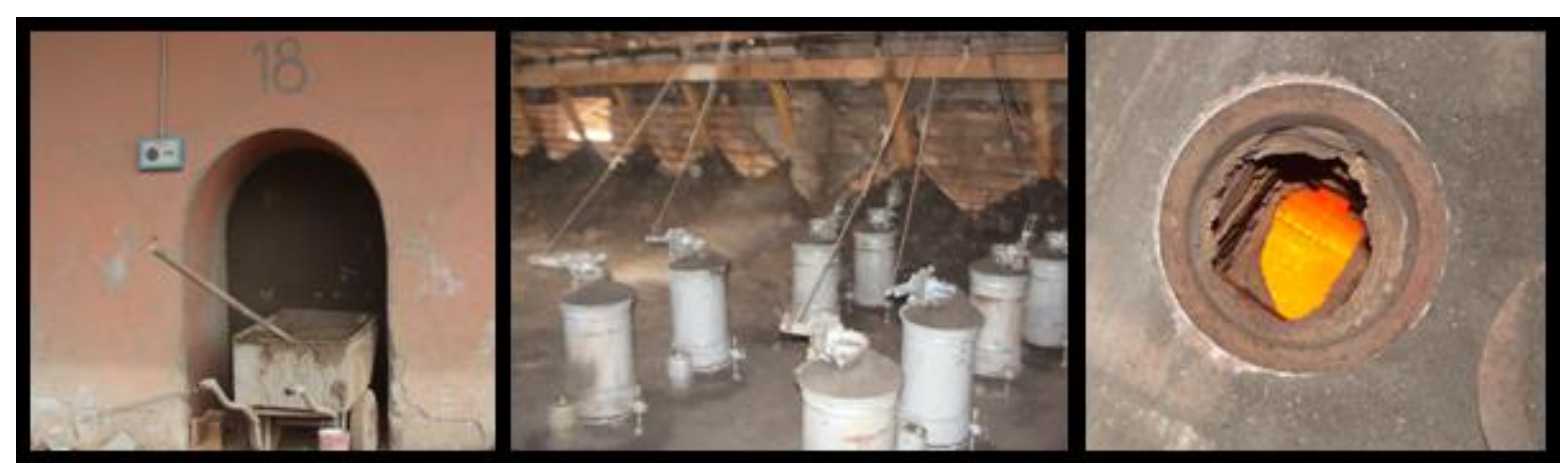

Figure 4. Firing of handmade bricks in the kiln

Unit weight, water absorption for 24 hours, capillarity, ultrasonic pulse velocity and compressive strength tests were applied in all specimens. Leveling made bottom and the upper surface of the title before compression test to provide smoothness of the surface exactly shown in Figure 5. 


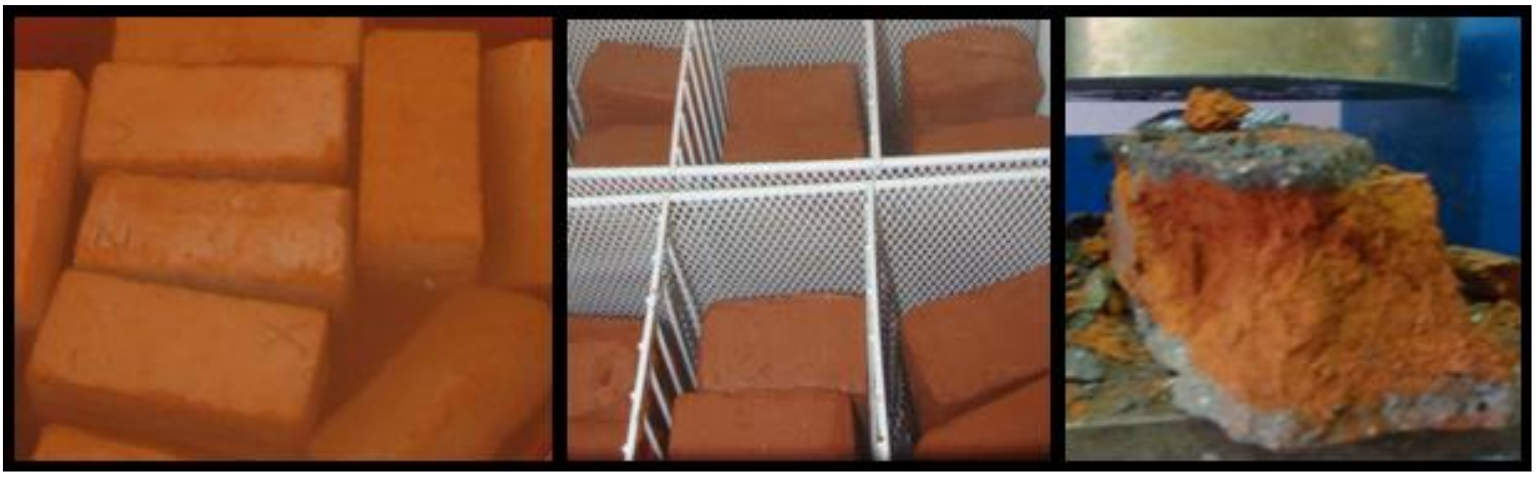

Figure 5. Handmade bricks with bottom ash and the tests

Unit weight of control and test samples, ultrasonic pulse velocity, dynamic modulus of elasticity, water absorption ratio, coefficient of capillarity and compressive strengths were determined. On the other hand the samples were waited at $\pm 20{ }^{\circ} \mathrm{C}$ for 50 and 100 freeze-thaw cycles. Freezing-Thawing durability affect were determined using unit weight, ultrasonic pulse velocity and compressive strength tests, so the effect of bottom ash to losses caused by freeze-thaw were determined according to control samples and shown as graphics.

\section{TEST RESULTS}

\subsection{Unit Weight and Ultrasonic Pulse Velocity}

Unit weight and ultrasonic pulse velocity of control samples and samples with bottom ashes are seen in Figure 6. According to figure, ultrasonic pulse velocities varies between $2.2-3.4 \mathrm{~km} / \mathrm{sec}$ while unit weights varies between $0.9-1.6 \mathrm{~kg} / \mathrm{dm}^{3}$. However weight percentage of bottom ash increases ultrasonic pulse velocity and unit weight decreases.

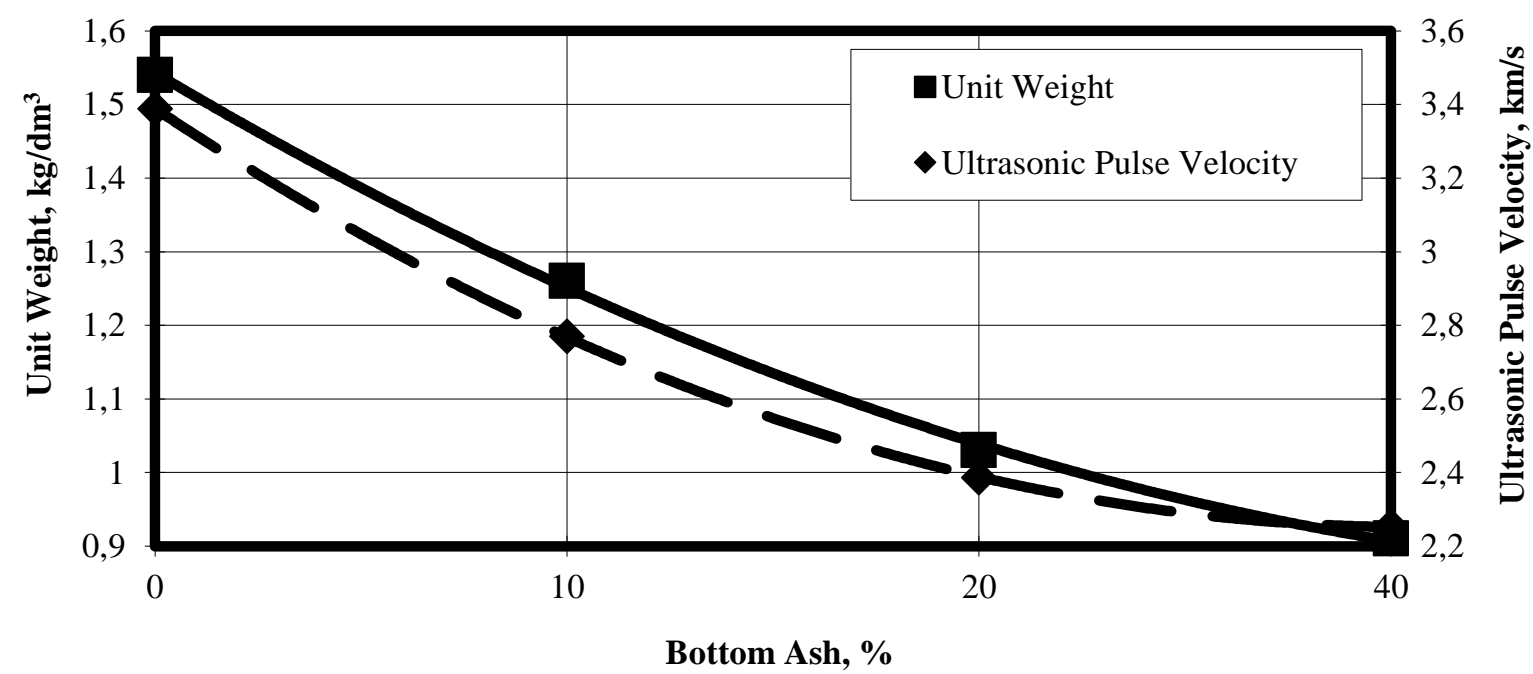

Figure 6. The changes in ultrasonic pulse velocity and unit weight with bottom ash ratio

\subsection{Water Absorption and Capillarity Coefficients}

The variation of water absorption and capillarity coefficients all samples are seen in Figure 7. Water absorption varies in the range of 19-45\% and coefficient of capillarity changes in the range of 0.00025 $0.0006 \mathrm{~cm}^{2} / \mathrm{s}$. Coefficient of capillarity raise until $20 \%$ bottom ash ratio then decreases. Bottom ash ratio 
increase then water absorption ratio also increase. This augmentation is jump to $20 \%$ bottom ash ratio but beyond this point the rate of increment decrease. It is seen that water absorption ratio is more than $20 \%$ which is specified on standards. In buildings, brick infill walls do not exposure to waters directly thus brick walls absorb water capillary and caused distortions.

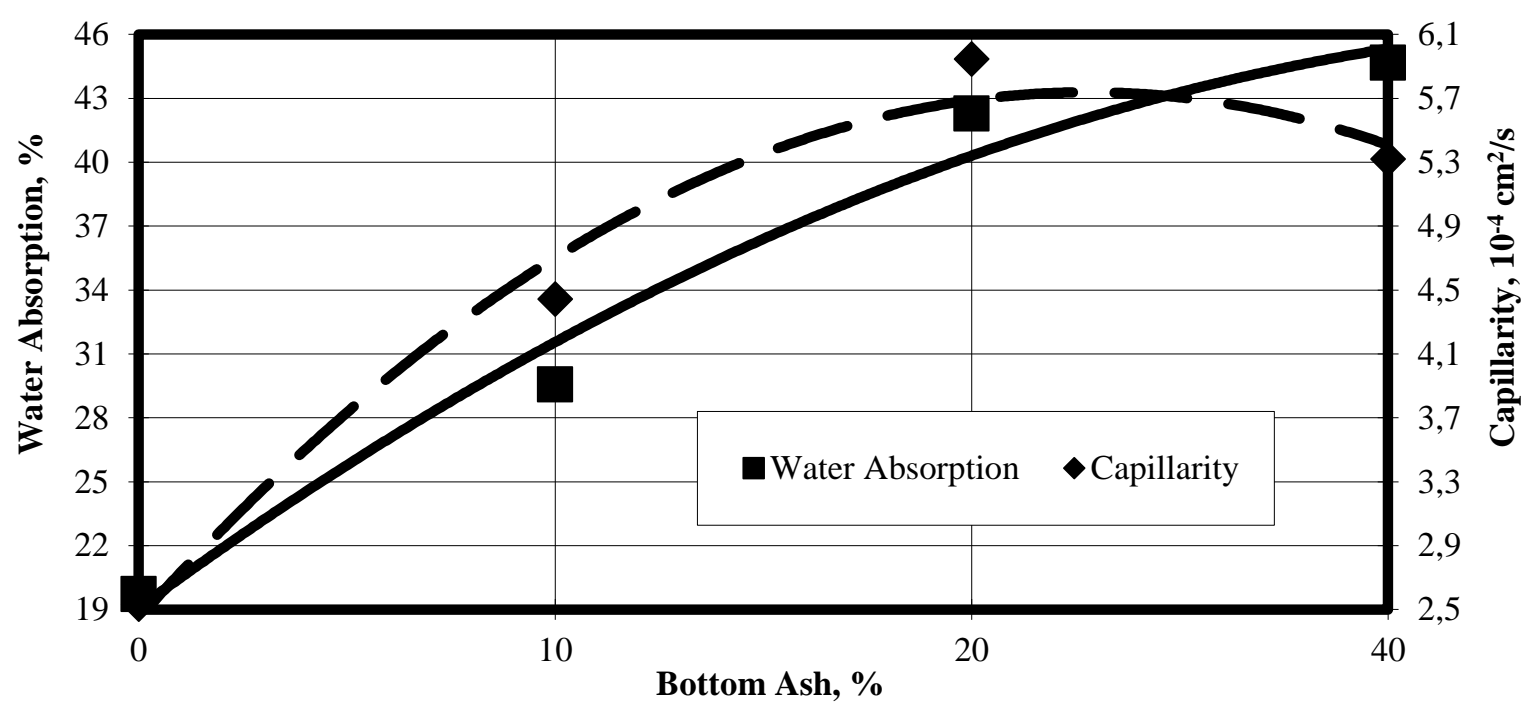

Figure 7. The changes in coefficients of capillarity and water absorption with bottom ash ratio

\subsection{Dynamic Modulus of Elasticity and Compressive Strength}

Dynamic modulus of elasticity and compressive strength of all samples are seen in Figure 8. According to the graphic, dynamic modulus of elasticity varies between $4.7-18 \mathrm{GPa}$ and compressive strength varies between 2.5-15 MPa. Bottom ash ratio increase then dynamic modulus of elasticity and compressive strength also increases. The average compressive strength of handmade bricks is almost 5 $\mathrm{MPa}$ while the minimum value should be $4 \mathrm{MPa}$ in accordance with codes. In this study, average strength handmade bricks are to be obtained using $10 \%$ bottom ash ratio, more than this ratio low-strength handmade bricks produced. The compressive strengths of the handmade bricks with $10 \%$ or less bottom ash ratio produced in this study is more than the bricks commercially available.

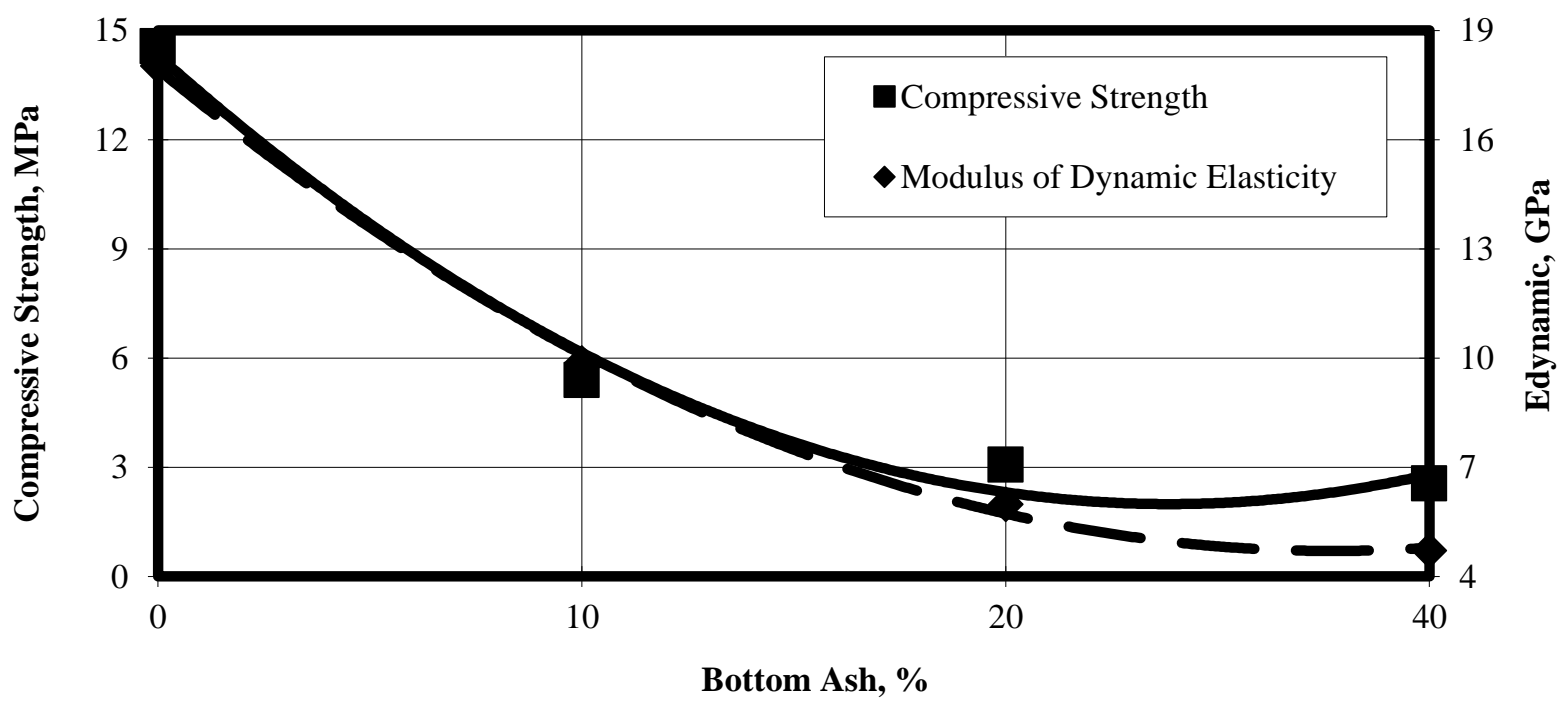

Figure 8. The changes in dynamic modulus of elasticity and compressive strength with bottom ash ratio 


\subsection{Test Results under Freeze-Thaw Cycles}

Changes in the unit weights of handmade bricks under freeze-thaw effect can be shown in Figure 9 . While the number of freeze-thaw cycle going up, the unit weights also increase sharply but after 50 cycle decreases. Melted waters are passing through the cracks while the ice inside the bricks are thawing, and as a result the unit weights of handmade bricks rise. Especially this increment in samples with bottom ashes more than control samples because of bottom ash can chemically binds water in structure. Under freeze-thaw effect cracking and chipping off effects seen on bricks and its caused unit weight decrement.

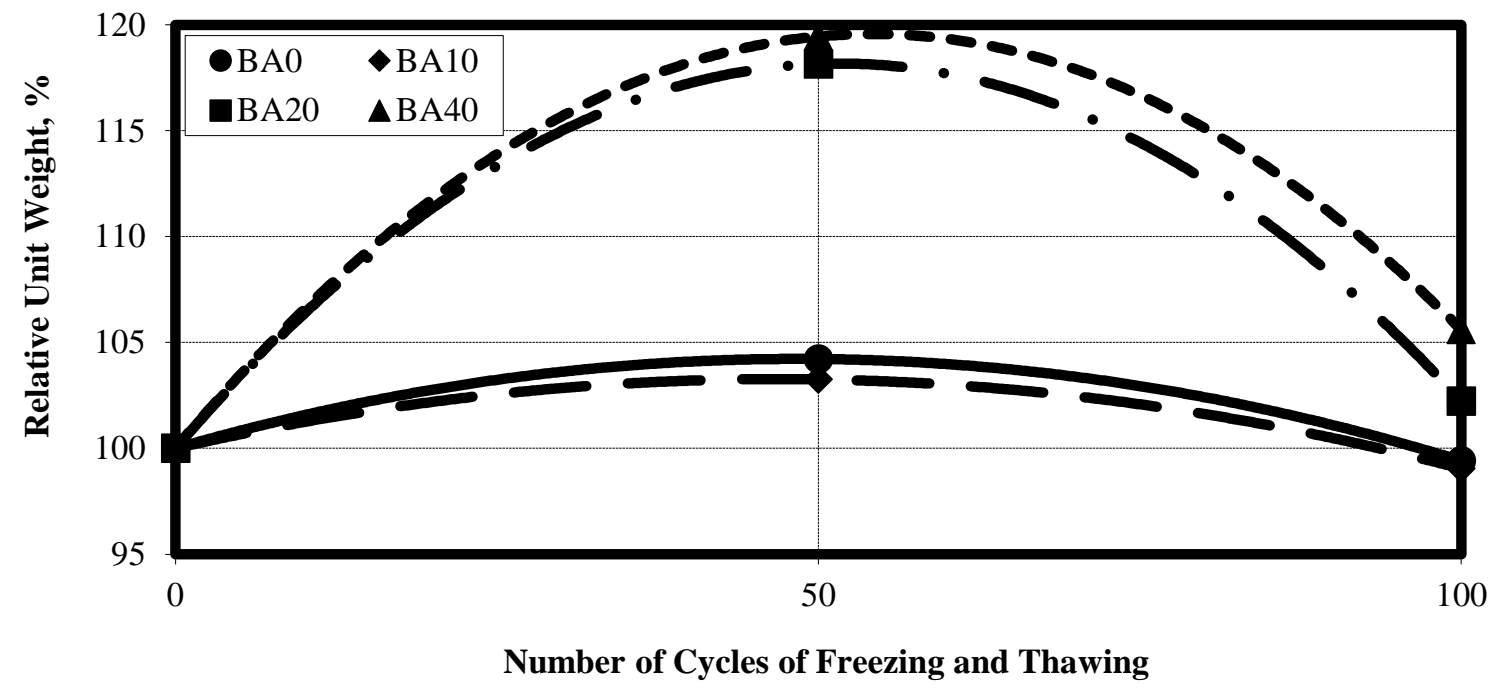

Figure 9. The changes in unit weights with freeze-thaw cycle for handmade bricks

Number of freeze-thaw cycle and ultrasonic pulse velocity losses of handmade bricks are seen in Figure 10. According to the graphic, Ultrasonic pulse velocities decreases in the range of $2.5-11 \%$ with increase in cycle number. Crack and gaps caused by freeze-thaw decreases. The major loss on number of freezethaw cycle and ultrasonic pulse velocity are in control samples. Minor loss occurs in the samples with $10 \%$ bottom ash ratio.

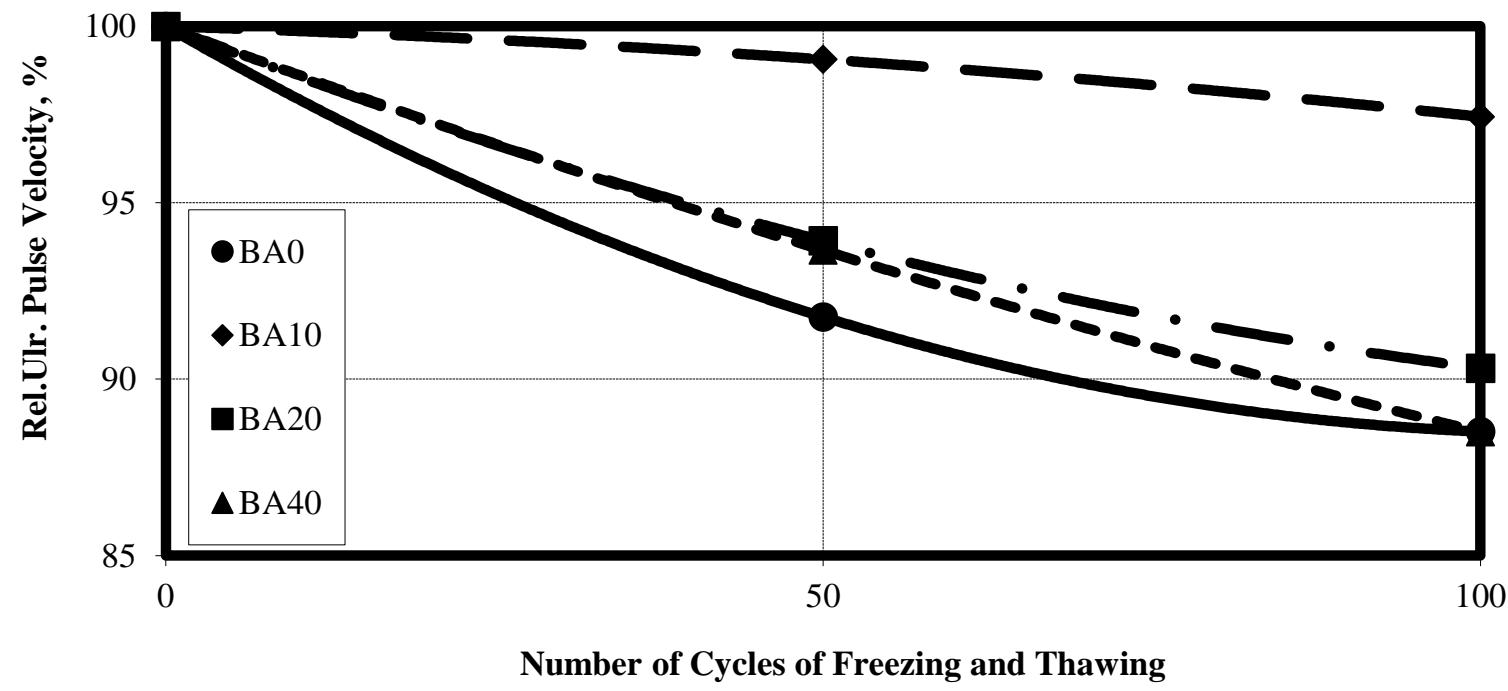

Figure 10. The changes in ultrasonic pulse velocity with freeze-thaw cycle for handmade bricks 
Number of freeze-thaw cycle and dynamic modulus of elasticity of all samples are seen in Figure 11. According to the graphic, dynamic modulus of elasticity of control samples decreases up to $22 \%$ with freeze-thaw cycle number raise. Dynamic elasticity modulus of specimens with bottom ash raise to $7 \%$ initially, after this point decrease up to $17 \%$. Reaction of bottom ash with water in progress so gaps in structure decreases.

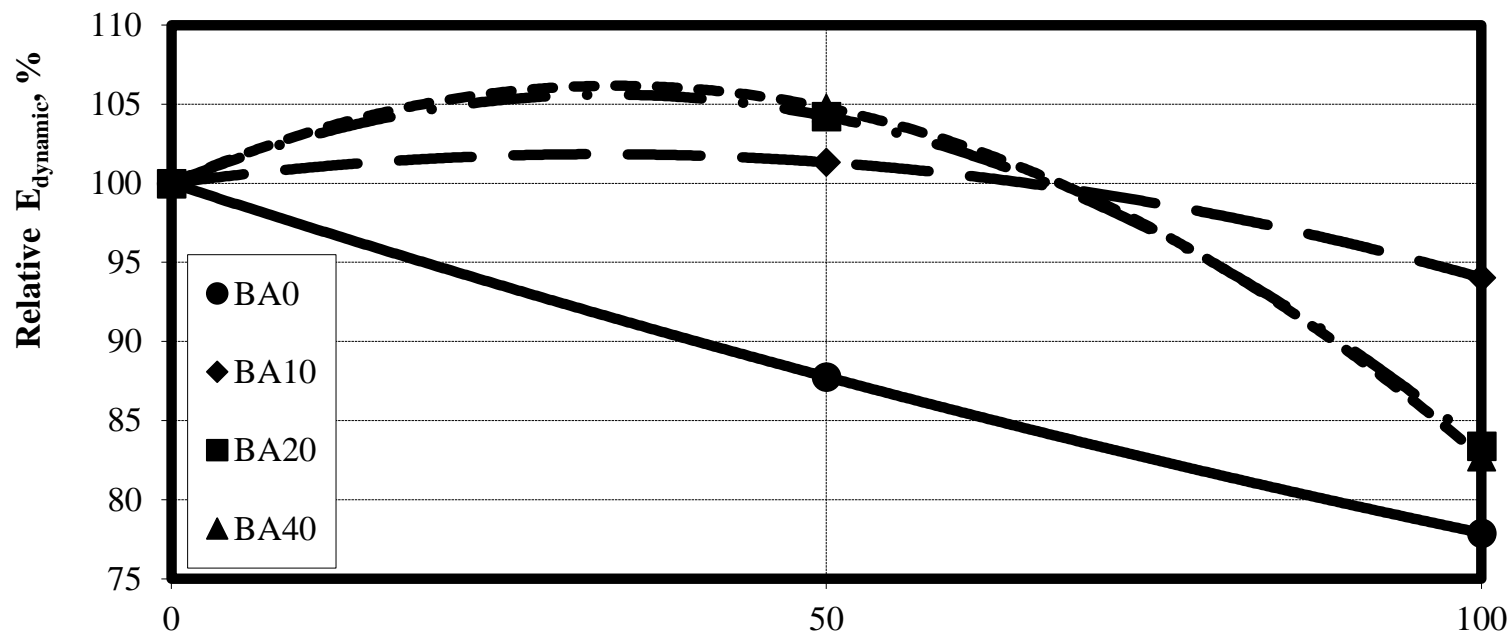

Number of Cycles of Freezing and Thawing

Figure 11. The changes in dynamic modulus of elasticity with freeze-thaw cycle for samples with bottom ash

Changes in compressive strengths of the specimens under freeze-thaw effect shown in Figure 12. Freezing thawing cycle number increase while compressive strengths dropped to $45 \%$. This reduction emerged at 100 cycles for bricks which has $10 \%$ bottom ash ratio, at 50 cycles for the samples with $20 \%$ bottom ash ratios, at 50 cycles for the samples with $40 \%$ bottom ash ratios, at 100 cycles for the samples with $45 \%$ bottom ash ratios.

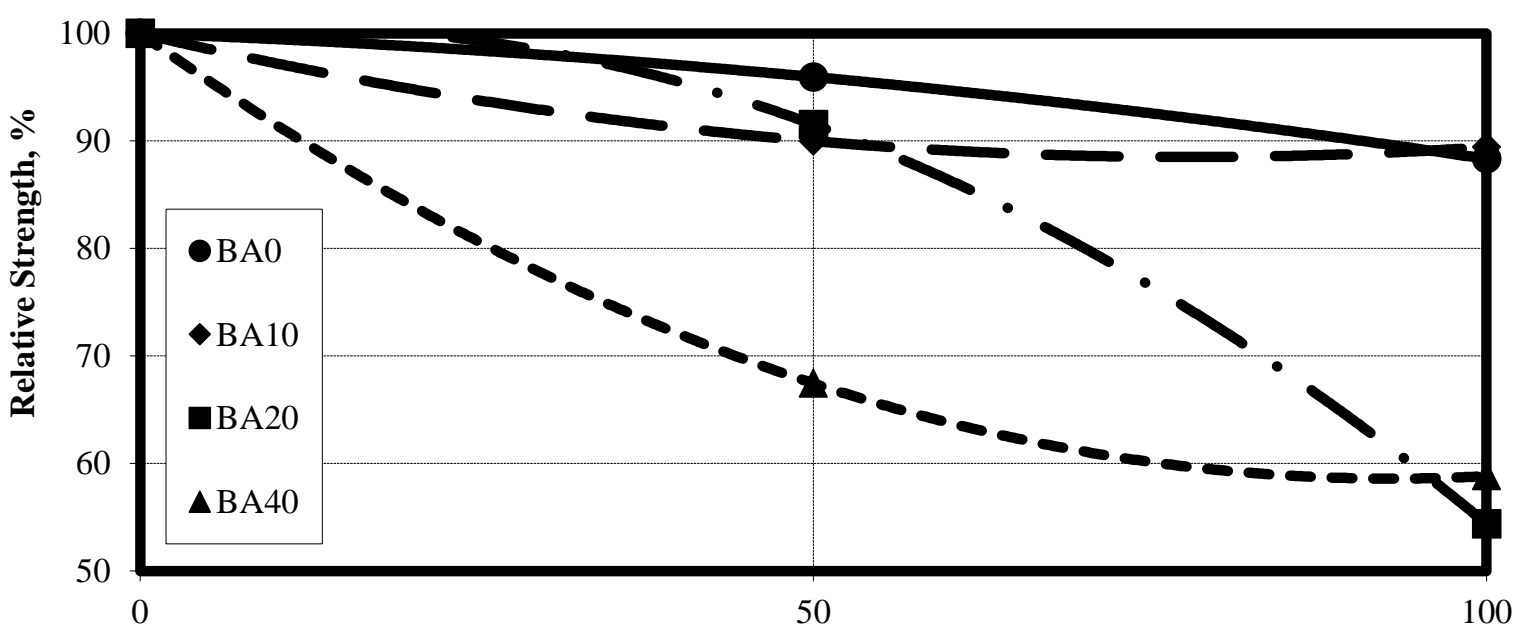

Number of Cycles of Freezing and Thawing

Figure 12. The changes in compressive strengths for samples with bottom ash 


\section{CONCLUSIONS}

The conclusions of the study are summarized as follows:

- The weight percentage of bottom ash increase ultrasonic pulse velocity and unit weight of handmade bricks decreases.

- The strength of brick is affected by the capillarity. In control samples water absorption is $20 \%$ while the ratio raise up $45 \%$ by addition of bottom ash on the other hand capillarity coefficient is 0.00025 $\mathrm{cm}^{2} / \mathrm{s}$ for control samples this ratio up to $0.00060 \mathrm{~cm}^{2} / \mathrm{s}$ by addition of bottom ash.

- Addition of high amount of bottom ash, dynamic modulus of elasticity and compressive strengths of handmade bricks decreases up to $85 \%$. Average strength ancient style bricks can be obtained while the bottom ash ratio is less than $10 \%$. The compressive strengths of the handmade bricks with $10 \%$ or less bottom ash ratio produced in this study.

- Unit weights under freeze-thaw effects increases by increment of water ratio for brick samples initially but decreases by increment of cracks. The increase of cracks cause decreases in ultrasonic pulse velocities of bricks. Dynamic modulus of elasticity of the samples with bottom ash decreases approximately $15 \%$ after 100 freeze-thaw cycles. Compressive strengths decreases $10 \%$ for the samples with $10 \%$ bottom ash ratio and $45 \%$ for the other samples under freeze-thaw effects. When the effects of bottom ash ratios replaced by clay and the freeze-thaw effect at different cycle numbers were discussed; mechanical behavior of baked clay is very different from bottom ash hence the contribution of bottom ash on the strength of brick is limited compering to clay.

In this study reducing the weight of handmade bricks using bottom ash is aimed. If the productions of handmade bricks do not done properly and in suitable conditions the strength of the bricks will be low. As a result using $10 \%$ bottom ash in production of handmade bricks can be proposed. Handmade bricks with bottom ash are mid-strength so must be used carefully in terms of load bearing and do not used high buildings. In addition, the effect of bottom ash usage on the durability of brick against various chemical and physical effects should be investigated.

\section{REFERENCES}

[1] Lopez-Arcea P, Garcia-Guinea J, Weathering traces in ancient bricks from historic buildings, Building and Environment, 2005; 40 929-941.

[2] Canbaz M and Albayrak U. Utilization of Bottom Ash in Lightened Harman Brick Production. ACE 2012. METU. Ankara. 2012.

[3] Oral EL, Mistıkoğlu G, Competitive analysis of the Turkish brick industry - a case study for developing countries, Building and Environment, 2007; 41, 416-423.

[4] Naganathan S, Subramaniam N, Mustapha KNB, Development of brick using thermal power plant bottom ash and fly ash, Asian Journal of Civil Engineering (Building and Housing), 2012; 13275 287.

[5] Canbaz M, Albayrak U. Freeze-thaw durability of blended harman bricks that used as infill material in reinforced concrete framed buildings, APCBEE Procedia, 2014; 9 258-263.

[6] Demir İ, Başpınar S, Orhan M, Utilization of kraft pulp production residues in clay brick production, Building and Environment, 2005; 40 1533-1537. 
Canbaz and Albayrak/Anadolu Univ. J. of Sci. and Technology A-Appl. Sci. and Eng. 19(1)-2018

[7] Monteiro SN, Vieira CMF. On the production of fired clay bricks from waste materials: A critical update, Construction and Building Materials, 2014; 68 599-610.

[8] Kızgut S, Çuhadaroğlu D and Çolak K. Investigation of brick production using fly ash from Çatalağzı Thermal Power Station, 17. International Mining Congress, pp 81-85, Ankara, Turkey, 2001.

[9] Bideci A, Bideci ÖS. An investigation into the usability of diatomite in brick production. Trakya Univ J Sci, 2008; 8, 69-76.

[10] Arioz O, Tokyay M and Arioz E. Properties of fly ash-FGD gypsum-lime based products. Journal of the Australasian Ceramic Society, 2006; 42.1 13-21.

[11] Topçu İB, Işıkdağ B. Manufacture of high heat conductivity resistant clay bricks containing perlite, Building and Environment, 2007; 42, 3540-3546.

[12] Kavas T. Use of boron waste as a fluxing agent in production of red mud brick, Building and Environment, 2006; 41, 1779-1783.

[13] Demir İ. An investigation on the production of construction brick with processed waste tea, Building and Environment, 2006; 41, 1274-1278.

[14] Raut S, Ralegaonkar R, Mandavgane S. Utilization of recycle paper mill residue and rice husk ash in production of light weight bricks, Archives of Civil and Mechanical Engineering, 2013; 13, 269275

[15] Munoz P, Morales MP, Mendívil MA, Juarez MC, Munoz L. Using of waste pomace from winery industry to improve thermal insulation of fired clay bricks. Eco-friendly way of building construction, Construction and Building Materials, 2014; 71, 181-187.

[16] Sütçü M, Alptekin H, Erdoğmuş E, Er Y, Gencel O. Characteristics of fired clay bricks with waste marble powder addition as building materials, Construction and Building Materials, 2015; 82, 1-8.

[17] Çiçek T, Tanrıverdi M. Lime based steam autoclaved fly ash bricks, Construction and Building Materials, 2007; 21, 1295-1300.

[18] Yildı K. Utilizitaion of different waste bricks in brick production, Construction Technologies ejournal, 2008; 4 31-41.

[19] Gencel O. Characteristics of fired clay bricks with pumice additive, Energy and Buildings, 2015; $102,217-224$.

[20] Naganathan S, Mohamed AYÖ, Mustapha KN. Performance of bricks made using fly ash and bottom ash, Construction and Building Materials, 2015; 96, 576-580.

[21] Topçu İB and Toprak MU Properties of geopolymer from circulating fluidized bed combustion coal bottom ash. Materials Science and Engineering, 2011; Vol 528, pp 1472-1477.

[22] Aubert JE, Gasc-Barbier M, Hardening of clayey soil blocks during freezing and thawing cycles, Applied Clay Science, 2012; 65-66 1-5.

[23] Binal A, Kasapoğlu KE and Gökçeoğlu C. Variation of some physical and mechanical parameters of the volcano sedimentary rocks around Eskişehir-Yazllıkaya under freezing thawing effect, Bulletin of Earth Sciences Application and Research Centre of Hacettepe University, 1997; 19 17-40. 